\title{
Kültür ile kanıtlanmış akciğer dışı tüberküloz: ilaç duyarlılığı ve genetik profil analizi
}

\author{
Mehmet Sezai \\ TAŞBAKAN ${ }^{1}$ \\ Damla AKDAĞ $\breve{G}^{2}$ \\ Hasip KAHRAMAN ${ }^{3}$ \\ Deniz AKYOL ${ }^{2}$ \\ Meltem TAŞBAKAN ${ }^{2}$ \\ Cengiz ÇAVUŞOĞLU 4
}

${ }^{1}$ Ege Üniversitesi Tıp Fakültesi, Göğüs Hastalıkları Anabilim Dalı, İzmir, Türkiye

${ }^{1}$ Department of Chest Diseases, Faculty of Medicine, Ege University, Izmir, Turkey

2 Ege Üniversitesi Tıp Fakültesi, İnfeksiyon Hastalıkları ve Klinik Mikrobiyoloji Anabilim Dalı, İzmir, Türkiye

2 Department of Infectious Diseases and Clinical Microbiology, Faculty of Medicine, Ege University, Izmir, Turkey

${ }^{3}$ Datça Devlet Hastanesi, İnfeksiyon Hastalıkları ve Klinik Mikrobiyoloji Kliniği, Muğla, Türkiye

${ }^{3}$ Clinic of Infectious Diseases and Clinical Microbiology, Datca State Hospital, Mugla, Turkey

${ }^{4}$ Ege Üniversitesi Tıp Fakültesi, Tıbbi Mikrobiyoloji Anabilim Dalı, İzmir, Türkiye

${ }^{4}$ Department of Medical Microbiology, Faculty of Medicine, Ege University, Izmir, Turkey

\section{ÖZET}

Kültür ile kanıtlanmış akciğer dışı tüberküloz: ilaç duyarııı̆̆ı ve genetik profil analizi

Giriş: Tüberküloz genel olarak akciğerlerde görülmekle birlikte tüm organları etkileyebilmektedir. Ancak akciğer dışı tutulum olduğunda tanı koymak, akciğer tutulumundan daha zordur. Mycobacterium tuberculosis'in izole edilmesi, ekstrapulmoner tüberküloz (EPTB) tanısında altın standart olmasına karşın, özellikle EPTB'de bakteriyolojik izolasyon oranı düşüktür. Eğer M. tuberculosis elde edilebilirse, hastalığın epidemiyolojik özellikleri ve ilaç duyarlılığı hakkında bilgi vermektedir.

Materyal ve Metod: Bu çalışmada, 2009-2016 yılları arasında mikobakteriyoloji laboratuvarında M. tuberculosis izole edilen ekstra pulmoner örnekler değerlendirilmiştir. İzole edilen bakterilerin genotiplerin belirlenme işlemi ve ilaç duyarlılık testleri yapılmıştır. Spoligotipleme, daha önce tarif edilen standart bir teknik kullanılarak gerçekleştirilmiştir.

Bulgular: Çalışma süresince 165 hastaya ait 171 ekstrapulmoner örnekte M. tuberculosis (75 erkek, 90 kadın, ortalama yaş: $53.35 \pm$ 19.92) kültürde üretilmiştir. Birden fazla ekstrapulmoner organ tutulumu 6 hastada mevcuttur. En yaygın EPTB şekli 60 hastada lenf nodu, 32 hastada plevral tüberküloz ve 25 hastada kemik tüberkülozdur. Yedi hasta insan immün yetmezlik virüsüyle infekte olmak üzere 44 hastada immün yetmezlik saptanmıştır. Tüberküloz ilaç direnci 175 örneğin 21'inde tespit edilmiştir. Rifampisin direnci 7 örnekte, yüksek düzeyde izoniazid direnci 11 örnekte ve rifampisin ve izoniazid direnci (çoklu ilaç direnci) 6 örnekte gösterilmiştir. Tüberküloz hastalarının farklı örneklerinden elde edilen 135 klinik izolatın genetik profili Spoligotyping kullanılarak belirlenmiştir. Majör Spoligotipler, $T$ ( $n=62 ; \% 45.9)$, LAM7-TUR (ST41) ( $n=11$; $\% 8.1)$ ve $H_{1}(n=9 ; \% 6)$ genotipleridir.

\section{Yazışma Adresi (Address for Correspondence)}

Sonuç: En yaygın EPTB şekli, kültürle kanıtlanmış hastalarda lenf nodu tüberkülozudur. Bu hasta grubunda, çoklu ilaç direnci oranı düşüktür (\%3.6). Spoligotip T (\%45.9) en sık görülen genetik profil olarak tespit edilmiştir.

Anahtar kelimeler: Tüberküloz; spoligotipleme; ilaç duyarlılı̆̆ı

Dr. Meltem TAŞBAKAN

Ege Üniversitesi Tıp Fakültesi, İnfeksiyon Hastalıkları ve Klinik Mikrobiyoloji Anabilim Dalı, IZMiR - TÜRKIYE

e-mail: tasbakan@yahoo.com 


\section{SUMMARY}

Culture proven extra pulmonary tuberculosis: drug susceptibility and genetic profile analysis

Introduction: Tuberculosis is seen generally in the lungs. Besides, all organs in the body can be affected by tuberculosis. Diagnosis of extra pulmonary tuberculosis (EPTB) is more difficult than pulmonary tuberculosis (PTB). Although, the isolation of Mycobacterium tuberculosis is gold standard of diagnosis of EPTB, the rate of bacteriologic isolation is low especially in EPTB. If M. tuberculosis is detected, it gives some information about the epidemiological features of the disease and drug susceptibility.

Materials and Methods: In this study, extra pulmonary samples isolated M. tuberculosis in mycobacteriology laboratory were evaluated between 2009-2016. The identification of the genotype of isolated bacteria and drug sensitivity tests were conducted. Spoligotyping was accomplished using a standard technique as described previously.

Results: During the study period, M. tuberculosis were cultured in 171 extra pulmonary samples of 165 patients (75 male, 90 female, mean age: $53.35 \pm 19.92$ ). Initial direct microscopically examination was revealed M. tuberculosis in 44 patients. There were more than one extra pulmonary organ involvement in six patients. The most common EPTB forms were lymph node TB in 60 patients, pleural tuberculosis in 32 patients and bone tuberculosis in 25 patients. Immunosuppression was detected in 44 (\%26.6) patients. Among these, seven patients were infected with HIV. In 21 of 175 samples, drug resistance was detected. Rifampicin resistance in 7 samples, high level isoniazid resistance in 11 samples and rifampicin plus isoniazid resistance (multiply drug resistance) in 6 samples were demonstrated. One hundred thirty-five clinical isolates were cultured from tuberculosis patient's different samples, of which the genetic profile was determined by using Spoligotyping. The major Spoligotypes were $T(n=62 ; 45.9 \%)$, LAM7-TUR (ST41) ( $n=11$; $8.1 \%)$ and $H_{1}(n=9 ; 6 \%)$ genotypes.

Conclusion: The most common EPTB form was lymph node tuberculosis in culture proven patients. In these patients group, multiply drug resistance rate was low (3.6\%). Spoligotypes $T(45.9 \%)$ was detected as most common genetic profile.

Key words: Tuberculosis; spoligotyping; drug susceptibility

\section{Giriş}

Tüberküloz başlıca akciğer ve plevrayı tutmakla birlikte, vücuttaki her organı etkileyebilen bir hastalıktır (1). Akciğer dışında yerleşen ve ekstrapulmoner tüberküloz (EPTB) adı altında toplanan, çeşitli doku ve organların tüberkülozu, sinsi olarak ilerleyerek birincil infeksiyondan yıllar sonra ortaya çıkabileceği gibi hızlı ilerleyerek akut bir tabloya da neden olabilmektedir (2). Sağlık Bakanlığı'nın Türkiye'de Verem Savaşı 2017 Raporu verilerine göre 2015 yılında 12.772 olgu tüberküloz tanısı almıştır (3). Hastaların 7598'inde (\%59.5) akciğer tutulumu, 4548'inde (\%35.6) akciğer dışı organ tutulumu saptanırken 626 (\%4.9) hastada hem akciğer hem de akciğer dışı tutulum gösterilmiştir (3). Ülkemizde 2005 yılı verilerinde akciğer dışı tüberküloz oranının \%28.6 (n= 5359)'dan 2015'de \%35.6 ( $n=4548)^{\prime}$ ya ulaşması EPTB olgularında sayısal artma olmamakla birlikte tüm tüberküloz hastaları içerisinde yüzdelik oranın arttığını göstermektedir (3).

Tüberküloz tanısında altın standart kültürde etkenin üretilmesidir. Ancak EPTB'de tanı akciğer tüberkülozundan daha zordur. Çünkü etken için örnekleme yapmak veya etkeni izole etmek her zaman mümkün olamamaktadır. Kültürde Mycobacterium tuberculosis'in üretilmesi kesin tanı koymayı sağlamakla birlikte, sürveyans ve ilaç duyarlıı̆̆ çalışmalarının yapılmasınada imkan sağlayabilmektedir. Kültürde etkenin saptanmasının bir avantajı ise korunma ve kontrole yönelik programların geliştirilmesinde farklı tür ve genotiplerin ortaya çıkarılmasına yol açabilmesidir (4). Moleküler düzeyde yapılan sürveyansda; IS6110-RFLP (Restriction Fragment Length Polymorphism) spoligotiplendirme ve 12-15-24 lokuslu MIRU-VNTR (Mycobacterial Interspersed Repetetive Units-Variable Number of Tandem Repeat) yöntemleri veya bu yöntemlerin kombinasyonları kullanılabilir (4). En yaygın kullanılan yöntem spoligotiplendirmedir.

Bu çalışmada hastanemiz mikobakteriyoloji laboratuvarına gönderilen solunum örnekleri dışındaki örneklerden M. tuberculosis üreyen hastaların retrospektif olarak irdelenmesi, antitüberküloz ilaç duyarlılık ve genotiplerinin değerlendirilmesi amaçlanmıştır.

\section{MATERYAL ve METOD}

\section{Bakteri İzolatları}

Hastanemiz Tıbbi Mikrobiyoloji Anabilim Dalı Mikobakteriyoloji Laboratuvarı'na 2009-2016 yılları arasında rutin mikobakteriyolojik inceleme amacıyla gönderilen ekstrapulmoner örneklerden üretilen ve GenoTypeMTBDRplus (Hain-Life Science) kitiyle $M$. tuberculosis kompleks olarak tanımlanan izolatlar çalışmaya alındı. MGIT 960TB (BD Diagnostic, ABD) yöntemiyle izole edilen suşlarının antitüberküloz ilaç direnci de aynı yöntemiyle belirlendi. 


\section{Olgular}

M. tuberculosis izole edilen ekstrapulmoner tüberküloz tanısı alan olgular laboratuvarı kayıtlarından ve hastane veri tabanında kayıtlı hasta dosyalarından retrospektif olarak tarandı. Olguların yaşı, cinsiyeti, ek hastalıkları, infeksiyon odağı, anti-tüberküloz ilaç dirençleri ve genotiplendirmeleri irdelendi.

\section{İzolatların Genotiplendirmesi}

Bu amaçla spoligotiplendirme yöntemi kullanıldı. Uygulama spoligotiplendirme için hazırlanmış kit (Spoligotyping Kit; Isogen Life Science, Hollanda) üreticisinin tanımladığı şekilde gerçekleştirildi. Kısaca; kültürde üretilen izolatlardan elde edilen DNA'nın $5 \mu$ L'si polimeraz zincir reaksiyonu (PCR) işleminde kalıp DNA olarak kullanıldı. DR dizisini hedef alan biyotinle işaretli primerler kullanılarak DR bölgeleri arasındaki "spacer"lar amplifiye edildi. Amplifiye olmuş PCR ürünü mini blotter yardımıyla oligonükleotit bağlı bulunan nitroselüloz membran ile hibridize edildi. Membranla hibridize olmuş "spacer"lar HRP-konjugat ve substratla inkübe edildikten sonra membran X-Ray filmiyle muamele edildi ve hibridize olan "spacer"lar karecikler olarak görünür hale getirildi. Hibridize olmuş "spacer" in varlığı pozitif sinyal, "spacer" hibridizasyonunun olmaması ise negatif sinyal olarak değerlendirildi. Suşların spoligotip numaraları, ait olduğu küme ve aileler http:// www.pasteur-guadeloupe.fr veri tabanı kullanılarak belirlendi.

\section{Duyarlılık Testleri}

Duyarlılık testleri BACTEC MGIT 960 (BD Spark, ABD) otomatize sıvı sistemi kullanılarak yapıldı.
Direnç sınır değerleri rifampisin için $1.0 \mu \mathrm{g} / \mathrm{mL}$, izoniyazid için $0.1 \mu \mathrm{g} / \mathrm{mL}$, streptomisin için $1.0 \mu \mathrm{g} / \mathrm{mL}$ ve etambutol için $5.0 \mu \mathrm{g} / \mathrm{mL}$ olarak kabul edildi (5).

\section{BULGULAR}

Çalışmanın yapıldığı dönemde 165 (75 erkek), yaş ortalaması: $53.35 \pm 19.92$ (min: 2, max: 92) hastadan 171 örnekte $M$. tuberculosis üremesi saptanmıştır. Kırk dört hastada direkt mikroskopik incelemede asido rezistan basil görülmüştür. En yaygın EPTB formu 60 hastada (\%36.3) lenf nodu, 32 hastada (\%19.3) plevral tüberküloz ve 25 hastada (\%15.1) kemik tüberkülozuydu (Tablo 1). Altı hastada birden fazla organ tutulumu vardı. Hastaların ikisinde akciğer birinde deri tüberkülozu olmak üzere üç hastada geçirilmiş tüberküloz öyküsü bulunmaktaydı. Hastaların 44'ünde altta yatan immünsüpresyon tespit edildi. Sırasıyla 11 hastada diyabet, 10 hastada kronik böbrek yetmezliği, 8 hastada immünsüpresif tedavi alan romatolojik hastalık, 8 hastada hematolojik malignite, 7 hastada solid organ malignitesi, 7 hasta insan immün yetmezlik virüsüyle infekte ve 4 hastada böbrek nakli öyküsü bulunmaktaydı. Kültürde üreme saptanan 171 örneğin 21'inde ilaç direnci tespit edildi. Yedi örnekte rifampisin, 11 örnekte yüksek düzeyde izoniazid ve 6 örnekte rifampisin ve izoniazid direnci (ilaç direnci çoğalması) gösterilmiştir.

Yüz kırk dokuz klinik örnekte genetik profili Spoligotyping kullanılarak belirlenmiş̧ir. Majör Spoligotipler $T(n=62, \% 45.9)$, Lam7Tur $(n=11$, $\% 8.1)$ ve $\mathrm{H}_{1}(\mathrm{n}=7,6.6 \%)$ genotipleridir. T spolipotipi saptanan 62 hastanın 39'u kadındır. En çok görülen tipler ve cinsiyet dağılımları Tablo 2'de verilmiştir.

Tablo 1. EPTB dağııımı ve ilaç dirençleri

\begin{tabular}{|c|c|c|c|c|c|c|c|}
\hline & $\begin{array}{c}\text { Cinsiyet (erkek) } \\
\text { n }(\%)\end{array}$ & İmmünsüpresyon & ARB & MDR & Rifampisin $\mathbf{R}$ & INH 0.1 R & INH 0.2 R \\
\hline Lenf (60) & 23 & 15 & 20 & 1 & 1 & 2 & 4 \\
\hline Meninks (12) & 4 & 1 & 3 & 1 & 1 & 1 & 2 \\
\hline Plevra (32) & 19 & 3 & 5 & 2 & 2 & 3 & 3 \\
\hline Kemik-eklem (27) & 11 & 3 & 8 & 1 & 1 & 1 & 3 \\
\hline Gis (12) & 6 & 4 & - & - & 1 & & \\
\hline Ürogenital (6) & 2 & 1 & 2 & 1 & 1 & 2 & 2 \\
\hline Miliyer (6) & 2 & 3 & 4 & - & & & \\
\hline Deri (9) & 3 & 1 & 2 & - & & & \\
\hline Perikard (7) & 5 & 1 & 2 & - & & & \\
\hline
\end{tabular}


Tablo 2. Spoligotip, cinsiyet ve immünsüpresyon durumu dağı̆ımı

\begin{tabular}{|lccc|}
\hline Spoligotip aileleri & Sayı & $\begin{array}{c}\text { Kadın/ } \\
\text { Erkek }\end{array}$ & $\begin{array}{c}\text { Immünsüpresyon } \\
\text { durumu }\end{array}$ \\
\hline T1 & 62 & $39 / 23$ & 5 \\
LAM7-TUR & 11 & $6 / 5$ & 4 \\
H1 & 9 & $4 / 5$ & 4 \\
LAM3 ve S conv. & 7 & $3 / 4$ & 3 \\
H3 & 7 & $3 / 4$ & 1 \\
T2 & 7 & $4 / 3$ & 1 \\
U & 7 & $3 / 4$ & 4 \\
H4 & 5 & $3 / 3$ & 4 \\
S & 5 & $3 / 2$ & 2 \\
Pekin & 3 & $1 / 2$ & 1 \\
Tanımlanamayanlar & 14 & $7 / 7$ & 5 \\
(Orphan suşlar) & & & 5 \\
Diğer tipler & 12 & $3 / 9$ & \\
\hline & & & \\
\hline
\end{tabular}

\section{TARTIŞMA}

Ülkemizde tüberküloz görülme sıklığı son yıllarda azalmasına rağmen, bu olgular içindeki EPTB oranı yıllara göre artış göstermeye devam etmektedir (3). Ekstra pulmoner tüberküloz sıklığı \%8-24 arasında değişmekle birlikte immün yetmezlikli kişilerde $\% 12.1-\% 48.5$ arasında daha yüksek oranlarda görülebilmektedir $(6,7)$. Çalışmamızda da olguların $\% 26.6$ 'sında immün yetmezlik mevcuttu. Tüberküloz verem savaşı 2017 raporundaki EPTB'lerin dağılımına benzer olarak bizim olgularımızda da en sık tutulan bölgeler lenf nodu ve plevral tüberkülozdur, ülkemizde bu iki tutulumdan sonra en sık gastrointestinalperiton tüberküloz görülürken, çalışmamızda kemik tüberkülozu üçüncü sıklıkta görülmüştür. Akciğer dışı tüberkülozu olan 257 olgunun değerlendirildiği bir çalışmada, en sık lenf nodu, plevra ve kemik-eklem tüberküloz görüldüğü belirtilmiştir (8).

Dirençli tüberküloz olguları halk sağlığı açısından dünya çapında endişe yaratmaya devam etmektedir (9). Tüberküloz direnci tanımına bakıldığında, tek ilaca dirençli tüberküloz (rifampisin veya izoniazide), birden çok ilaca dirençli tüberküloz (rifampsin ve izoniazid direnci beraber olmamak kaydıyla en az iki birinci basamak ilaca), çoklu ilaca dirençli olgular (rifampisin ve izoniazide), yaygın ilaç direnci (rifampisin ve izoniazide ek, anti-TB ilaçlardan herhangi bir florokinolona ve parenteral kullanılan anti-TB ilaçlardan en az birine) karşı gelişen direnci ifade etmektedir (10). Dirençli tüberkülozun tedavisinde kullanılan ikinci basamak ilaçlar, birinci basamak ilaçlara göre daha toksik, etkinlikleri daha düşük ve maliyetleri daha yüksektir. Bu olguların tedavilerinin daha zor olması, tedavi ve hastanede yatış sürelerinin uzun olması bu olguların klinik olarak önemini arttırmaktadır (11). Türkiye'de Verem Savaşı 2017 raporunda tüm olguların \%21.3'ünde en az bir ilaca direnç saptanmıştır (3). Ilaç direnci bakılan olgularda izoniazid direnci \%13.7, rifampisin direnci \%5.4, izoniazid ve rifampisin direnci ise \%4.1 olarak tespit edilmiştir (3). Olgularımızda izoniazid direnci \%6.3, rifampisin direnci \%4, çoklu ilaç direnci ise \%3.4 oranında saptanmıştır. İzoniazid direnci ülke verilerine göre düşük bulunmakla birlikte rifampisin ve çoklu ilaç dirençleri benzer bulunmuştur.

Tüberkülozun toplum içerisindeki yayılımının değerlendirilmesi nedenlerinin anlaşılması ve daha etkili kontrol önlemlerinin geliştirilebilmesi için moleküler bazlı epidemiyolojik yöntemlerin yaygınlaşması gerekmektedir (4). Çukurova bölgesinde yapılan çalışmada akciğer tüberkülozlu olgulardan toplanan 467 örnek değerlendirilmiş, 239 (\%51.9) izolatta T1 ailesi, $54(\% 11.5)$ izolatta ise LAM7 TUR ailesi tespit edilmiş (4). Ankara ve Malatya bölgesine ait 245 örneğin değerlendirildiği diğer bir çalışmada \%21 LAM7 TUR, \%16.3 T1, \%5.3 oranında Haarlem 3 ailesi saptanmış (12). Malatya bölgesinden diğer bir çalışmada $450 \mathrm{M}$. tuberculosis izolatı değerlendirilmiş; T ailesi \%38.6, LAM7 TUR \%27.3, Haarlem ailesi ise \%14.8 oranında görülmüştür (13). Bizim çalışmamızdaki Majör Spoligotipler, $\mathrm{T}$, Lam7-TUR ve $\mathrm{H}_{1}$ genotipleridir. T tipi dışındakilerde kadın erkek oranı benzer olmakla birlikte T tipinde kadın hasta oranı yüksek bulunmuştur. Ancak diğer tiplerde hasta sayısının az olması nedeniyle bu konuda ayrıntılı yorum yapılamamaktadır.

\section{SONUÇ}

Bu çalışma kültür pozitif ADTB olgularında direnç ve genotip düzeyinde değerlendirmeyi irdeleyen en geniş çalışmalardan biridir. Bölgemizdeki tüberküloz suşlarının dağılımı hakkında epidemiyolojik veriler elde edilmiştir. Çalışmamızın kısıtlılıklarını değerlendirdiğimizde, çalışmanın retrospektif olarak planlanması, toplanan örneklerin İzmir ve çevresiyle sınırlı olması ve hasta takiplerinin tanı konulduktan sonra başka merkezlerde yapılması nedeniyle sağkalımları ile ilgili bilgi edinilememesi sayılabilir. Ülkemizdeki tüberküloz suşlarının genetik dağılımına ait epidemiyolojik verilerin artması ve bu verilerin yıllar içindeki değişimlerinin izlenmesiyle, hastalığın kontrol altında tutulabilmesi ve dirençli tüberküloz olgularının yayılımının önlenmesi sağlanabilir. 


\section{KAYNAKLAR}

1. Taşbakan MS, Pullukçu H, Sipahi OR, Işıkgöz Taşbakan M, Ozkören Çalık S, Yamazhan T. Evaluation of 694 tuberculous lymphadenitis cases reported from Turkey between 1997-2009 period by pooled analysis method. Mikrobiyol Bul 2010;44:385-93.

2. Aslan G, Ülger M, Delialioğlu N, Otağ ZF, Düşmez Apa D, Ersöz G, et al. Mersin ilindeki akciğer dışı tüberküloz olgularının mikrobiyolojik ve demografik olarak değerlendirilmesi. Türk Mikrobiyol Cem Derg 2017;47:197-204.

3. Türkiye Cumhuriyeti Să̆lık Bakanlığı Türkiye'de Verem Savaşı 2017 Raporu. https://hsgm.saglik.gov.tr/depo/ haberler/verem-savas-raporu-2016 2017/Turkiyede_ Verem_Savasi_2017_Raporu.pdf

4. Zeytinli U, Köksal F. Genotyping of Mycobacterium tuberculosis strains isolated from pulmonary tuberculosis patients in Cukurova Region, Turkey by spoligotyping and MIRU-VNTR methods. Mikrobiyol Bul 2012;46:202-10.

5. Clinical and Laboratory Standards Institute. Susceptibility testing of Mycobacteria, Nocardiae, and other aerobic Actinomycetes. Approved Standard M24-A2, Second Edition. CLSI, Wayne, PA, 2011

6. Naing C, Mak JW, Maung M, Wong SF, Kassim AIBM. Meta-analysis: the association between HIV infection and extrapulmonary tuberculosis. Lung 2013;191:27-34.

7. World Health Organization World Health Organization Global Tuberculosis Report, 2018. Available from: http://www.who.int/tb/publications/global_report/ archive/en/
8. Sunnetciog/u M, Baran Al, Binici I, Esmer F, Gultepe B. Evaluation of 257 extra pulmonary tuberculosis cases at the Tuberculosis Control Dispensary, Van, Turkey. I Pak Med Assoc 2018;68:764-7.

9. Prasad R, Kumar Srivastava D. Multi drug and extensively drug-resistant TB (M/XDR-TB) management: Current issues. Clinical epidemiology and global health 2013; 1:124-28.

10. Caminero JA, Sotgiu G, Zumla A, Migliori GB. Best drug treatment for multidrug-resistant and extensively drugresistant tuberculosis. Lancet Infect Dis 2010;10:621-9.

11. Baylan O. Çok ilaca dirençli tüberkülozdan sonra yaygın ilaca dirençli ve tüm ilaçlara dirençli tüberküloz formları: eski hastalı̆̆ın yeni yüzleri. Mikrobiyol Bul 2011;45:18195.

12. Zozio T, Allix C, Gunal S, Saribas Z, Alp A, Durmaz R, et al. Genotyping of mycobacterium tuberculosis clinical isolates in two cities of Turkey: description of a new family of genotypes that is phylogeographically specific for Asia Minor. MC Microbiol 2005:26;5:44.

13. Günal S. Türkiye'nin farklı coğrafik bölgelerinden toplanan Mycobacterium tuberculosis izolatlarının ıs6110 rflp (restrıctıon fragment length polymorphısm) ve spoligotip profillerinin belirlenmesi (tez). Malatya: Inönü Üniversitesi, 2006. 